\title{
Beyond irrationality and the ultras Some notes on female English rugby union fans and the 'feminized' sports crowd
}

\begin{abstract}
In the Academy, female fandom is often conceived of in ways which consciously exclude sport, and women are often marginalised by research on sports fandom. There is also little convincing qualitative research on the experience of mainstream female sports spectators, despite competing claims about the meaning and nature of today's alleged 'feminised' sports crowds. Much of the qualitative work which does exist in this field focuses on younger male soccer fans and pathologises the experience of female spectators. Instead, in this paper we explore the experiences of mainstream female fans from a sport which is much under-researched, English rugby union.

Drawing on qualitative data from semi-structured interviews with female rugby union fans from Leicester, we explore these women's fan experiences in the context of claims about the recent 'feminization' of the late-modern sports crowd. We focus empirically on three key issues: the early sports encounters of female spectators and their possible links with fandom; changes in women's access to leisure time and to spectator sport; and women's shifting experiences of watching rugby union in the new 'professional' era of the game. We end with a call for more qualitative work on the changing experience of female sports fans and for more theoretical and empirical work on the supposed 'feminised' sporting cultures of latemodernity.
\end{abstract}

Keywords: Female fandom marginalisation feminisation rugby union consumption

The experiences of female sports fans, especially non-soccer fans, have been largely

marginalised in academic research. This is despite claims that we have recently been witnessing 
a relative 'feminisation' of the sports crowd in England. Drawing mainly on interview data from mainstream female rugby union fans in the East Midlands city of Leicester, this article examines aspects of women's early connections with sport and explores some of their defining experiences as sports fans. We begin by assessing the existing research agenda on male and female fandom, before saying something about the debate about the so-called 'feminised' sports crowd. Our empirical findings focus on three key issues. Firstly, we consider the significance of early sporting experiences of female spectators; secondly we explore wider changes in women's access to leisure time and their relation to new opportunities for women as sport spectators; and, thirdly, we examine aspects of women's changing experiences of watching sport in the context of the 'feminising' debate.

\section{Gender and fandom}

As academics interested in sport and leisure we often forget - perhaps to our cost - that the term 'fan' derives from the word 'fanatic' which, as Jenkins (1992: 13) reminds us, has 'traditional links to madness and demonic possession.' However, specific associations are often made in this context that relate gender difference - and perhaps particularly types of femininity - to this rather grim portrayal of the fan archetype (Harris, 1998). The 'typical' image of female fandom represented here is of an enslaved victim; someone who is left, helplessly, 'sobbing and screaming and fainting, and assumes that an uncontrollable erotic energy is sparked by the chance to see or touch a male idol'. Typical male fandom is also pathologised, of course, but in a different way. It is usually one of, 'drunken destructiveness, a rampage of uncontrollable masculine passion that is unleashed in response to a sports victory or defeat' (Jenson 1992: 15). 
In short, existing public rhetorics about and perceptions of female fans typically position them as overly-emotional at best, and as irrational and uncontrollable at worst. In some respects male fans come off equally badly - as stereotypically impassioned, often violent, partisans. In academic research 'typical' female fans are devotees of soap operas (Ang, 1991; Harrington and Bielby, 1995; Spence, 2005); staunch viewers of reality TV shows (Kilborn, 2003); aficionados of pop bands (Cline, 1992; Ehrenreich, Hess and Jacobs, 1992; Hinerman, 1992); and starcrossed followers of movies/movie icons (Barbas, 2001; Taylor, 1989). But as Gosling (2007) and Mewett and Toffoletti (2008a) point out, women are not usually modelled as fans of sport, not even in academic journals devoted to questions of sport and leisure.

Much of the recent growth in research on sports fandom is characterised by a focus on changing patterns of consumption and, more especially in the United States, on quantitative studies driven by social psychology and sports marketing: a largely statistical concern aimed at measuring primary motivations for fandom (see Chen, 2010; Clark et al., 2009; Funk et al 2004; Robinson \& Trail, 2005; Smith \& Stewart, 2007; Wann. Melnick, Russell \& Pease, 2001). In the UK, this field is shaped rather differently. It has typically been more sociological and has focused on the ways in which the 'traditional' (male) working class sporting fan - usually soccer fans -and the local audience for 'live' sport have been argued to be increasingly threatened with marginalisation or even exclusion from active sport spectatorship (King, 2002; Nash, 2000; 2001; Williams \& Perkins, 1998). This is due, it is argued, to the connected processes of globalisation, gentrification, commodification and the television-promoted spectacularisation (and consequent cultural 'emptying out') which has characterised new directions in the 
production and consumption of much late-modern professional sport, perhaps especially professional soccer (Conn, 1997; Giulianotti, 1999; Nash, 2000; Sandvoss, 2003).

We have some sympathy with this work but we also think, pace Andrews' and Ritzer's (2007) recent critique of defenders of the primacy of local practices in late-modern sport, that it tends towards an underdog populism and nostalgia concerning the privileging of the actor and the local in British sport's masculinist and cultish past. This approach is also married to a somewhat static and underdeveloped conceptualisation of social class and an underplaying of the very real social and cultural changes in the way young people today - including many young women - connect with a wide range of cultural and leisure practices, including sport (see Williams, 2000). Relatively little attention has been focused in such accounts on the socialisation, fan career and normative experiences of female sports fans. This is probably because women are accused of usurping men in the late-modern sports stadium by eroding this so-called last bastion of exclusive masculinity (Crolley \& Long, 2001). Moreover, social science research also routinely makes invisible the experiences of core, older sports fans drawn from a wide range of social backgrounds. Recent critics of post-sub-cultural research on youth cultures stress how it has sidelined the 'ordinary' and the unspectacular in search of the expressive 'neo-tribes' of the latemodernity (Shildrick \& MacDonald, 2006). The same is true, we would argue, of research on sports fans. It marginalises the large majority who are typically not directly involved in collective processes of resistance or in highly expressive supporter cultures around their sport. By their omission these subjects are implicitly labelled as silent (often middle class) passive 'consumers' of sport: as market followers or 'dupes' who somehow lack the necessary cultural 
'authenticity' to interest academic researchers. For older, women sports fans this sort of marginalisation can count as a double-exclusion.

Those few existing studies of women sports fans typically posit them either as dysfunctional predators (Crawford \& Gosling, 2004; Mewett \& Toffoletti, 2008a), subordinate members of hooligan or ultras fan groups (Cere, 2003), or else as women differentially struggling to negotiate leisure space for themselves against the forces of historic forms of male sports privilege (see Jones, 2008). These are all important areas for reflection and study, of course. The (mainly male) subcultures of sports crowds require regular examination and exposure for their overlymasculinised symbolic and material codes of exclusion. But women fans emerge here as incomplete ciphers and certainly as highly contingent members of the sporting community. Our own contention is that there is more to female sports fans than their depiction as maligned, oversexualised and overly-assertive purveyors of heterosexual desire, or passive sidekicks to hypercommitted male terrace actors, or even their role as rather valiant, 'neo-feminist' resisters. In this sense, our research revisits Dietz-Uhler, Harrick and End's (2000: 227) assertion that: 'For females, being a sports fan means attending, watching and cheering at sporting events, preferably in the company of family and friends,' primarily by responding to Free and Hughson's (2003) calls to rectify the routine absence of female experiences and perspectives from academic work on sports fandom. Our work suggests that active female sports fans today exhibit a remarkably wide range of socialising influences, supporting styles, fan tropes, and 'career' trajectories as followers of sport. We explore some of these matters in more detail below. 


\section{Existing research on female sports fans and questions of crowd 'feminisation'}

Notwithstanding our comments above, there is some qualitative work on female sports fans, but it is a sparse field and it is mainly focused on soccer. There are also small signs of a new emphasis in historical research on the early years of female sports fandom (see Lewis, 2009). An exception to this strong soccer focus is Crawford and Gosling's (2004) account of young female resistors to (male) perceptions of British women ice hockey fans that they are simply predatory heterosexual 'puck bunnies' who stalk male players. Mewitt and Toffoletti's (2008a, 2008b) important recent work on female fans of Australian Football League (AFL) clubs centres on two issues: firstly, how women become fans of AFL clubs - like many men, it is mainly through family ties - and, secondly, the views of female fans on players' publicly revealed sexual misconduct against women. In terms of the former, here we do briefly hear the views of older female sports fans. In terms of the latter, younger female AFL fans divide between those who blame 'predatory women' for triggering sexual desire among the players, and those who identify a minority of 'rogue men' among professional sportsmen; athletes who exploit their sense of entitlement over women fans. In both accounts male footballers' actions were ultimately justified by women by drawing simultaneously on socio-cultural and essentialist arguments about gender behaviour. Mewitt and Toffoletti (2008a: 176) conclude that this strategy 'creates a space for them [women fans] to critique football culture while actively participating in it through their support of the game'.

A similar gender ambiguity and identity tension is found in Katherine Jones's (2008) recent excellent interview-based analysis of the experience of female soccer fans in Britain. Here the focus is on how women engage with 'insulting' masculine fan practices and the extent to which 
such engagement affects their identities as both women and fans. Jones shows that three strategies were adopted by female fans to respond to abusive masculine behaviour while negotiating their own gender identities in a sporting context. Firstly, by defining sexist and abusive behaviour as 'disgusting' women challenge the contemporary meaning and expression of male soccer fandom. Secondly, by simply downplaying sexist and homophobic abuse some women rationalise it by arguing it is directed at both men and women, and is therefore 'funny' and harmless, especially compared to racism. Thirdly, by embracing gender stereotypes as 'part of the game' female fans effectively collude with hegemonic masculine definitions of 'authentic' fandom, thus distancing themselves from the 'emphasized femininity' expressed by some female spectators which denotes they do not adequately 'do' fandom. In effect, Jones explores the way in which the duality between women's fan and gender identities is negotiated: that is, in sports crowds women typically demand to be identified as fans, rather than as female fans.

Exploring connected terrain, Rodríguez (2005: 238) shows how in Argentina, women were conventionally depicted in the national soccer discourse in 'domestic roles' (such as players' wives or girlfriends), but that reactions to the soccer World Cup finals of 1998 demonstrated that, 'their fandom was legitimately accepted in the domain of representations; women at that point became "national supporters." Sue Lopez (1997), similarly, has claimed that the 1966 World Cup win in England stimulated both a revival in English women's soccer and a surge of interest among female spectators. But much later it was the television production values of World Cup Italia '90, coupled with the marketing and modernisation brought by the commercial synergy of satellite TV and the aggressively marketised FA Premier League, which sparked a spurt of female soccer match attendance in England (Williams, 2006). In Italy, the World Cup 
successes and the conventionally heterosexual 'glamour' of the national team has been argued to be one reason why Italian soccer often commands more heterosexual female support than in other equivalent European societies (Cere 2003: 168).

We can see from even this brief review that processes of 'feminization' in sports crowds may have rather different meanings in different societies and contexts. In its most basic sense the term might refer simply to the opening up of more opportunities for women to become active sports spectators. Greater acceptance of women, by male fans, as 'authentic' in their fandom might follow, but we can also see that women have to 'earn' this legitimacy, including by policing the acceptable boundaries of their own fandom. In Britain the notion of the more 'feminized' crowd is also routinely bound up with the production of a preferred bourgeois 'family audience' for sport and it has often been used by sports clubs to refer to recent processes of stadium modernisation (especially in soccer) and the associated range of presumed economic, social and cultural 'civilising' effects of having increasing numbers of female spectators present at largely male sporting events (Crolley \& Long, 2001). In Italy, Cere (2003: 184) argues that women-only ultra groups (intensely partisan young Italian soccer fans), as well as women within male fan groups, can bring 'positive changes to the curve, especially in the light of the increase in racist and violent culture among some groups', with the 'curve' or 'curva' depicting the area of the football stadium where the ultras congregate, usually the curved stand behind the goals.

Elsewhere, 'feminization' in the sports crowd has denoted the impact of the effective latemodern marketing of the heterosexual attractiveness of sportsmen. For example, Kim (2004: 15) describes how South Korean women, 'transformed the soccer games into a space where they 
could project their sexual desires'. Many South Korean female fans are typically depicted as 'not even knowing the rules [sic], but just liking the players' (Kim 2004: 43). While, despite the supposed recent 'feminization' of Argentinean soccer, many men also 'believe women to be incapable of knowing anything about football, and they resist the idea that women can have a “real” passion' for the sport (Rodríguez 2005: 234). Instead, in sports crowds, ‘women's bodies become objects of some form of panoptic masculine gaze', and the male focus on 'young sexy women as a representation of all women' means that the range of females involved and their differential motives as soccer fans, are generally ignored (Rodríguez 2005: 239-240). China and Japan have also been similarly identified as having domestic sporting cultures where, 'celebrity figures are more prominent to attract new, especially female, supporters' (Giulianotti \& Robertson 2004: 555). In all these examples - from the UK, Australia, South Korea, Argentina, Japan and Italy - and despite the growing prominence of female sports fans in each case - there seems little scope for exploring what might be the collective interests of female sports spectators, for example by examining the extent and nature of continuities in spectator heritage for women or, indeed, by considering aspects of the relative de-domesticated heterogeneity of the female sport spectator experience today. Instead, spectator sport remains resolutely a place where it is largely male identities which can apparently be 'completed' (Rodríguez 2005: 233). In short, in the late-modern stadium and despite recent changes in the make-up of sports crowds, sport still tends towards a 'habituated action'; a doxa, which serves in its reproduction as a gendered cultural sphere (Mewett \& Toffoletti, 2008b: 7). 


\section{A note on methodology}

In our own research on sports crowds in England we want to add to our knowledge of the largely 'invisiblised' older, non-soccer female sports fan. We do this by briefly reporting on the sporting background, experiences and motivations of a sample of 22 older adult female fans of one prominent English professional rugby union club, the Leicester Tigers. These data have been extracted from a wider, comparative semi-structured interview study of female rugby union and soccer fans in the English East Midlands city of Leicester (Pope, 2010). Our respondents were drawn from a sampling frame of rugby union fans produced by a national postal questionnaire survey conducted in 2003 (Williams, 2003). The resultant recorded interviews typically lasted between one and two hours, and were usually conducted in the homes or work places of respondents. All were conducted by a young female researcher and co-author of this paper; the field researcher was often faced in this task by male (usually husband/partner) intrusions or by other forms of male 'policing' of female research (Deem, 1986). This is a further indicator, of course, of the highly marginal role allocated by men, to women, as sports spectators (Pope, 2008).

Unusually for England, Leicester hosts prominent professional sports clubs in both the soccer (Leicester City FC) and rugby union codes, thus reflecting in one single urban location the historic social class and regional bifurcation of the rival male winter team sports in England (Harvey, 2005; Collins, 2009). Historically, club rugby in England drew much smaller crowds than soccer, but the professionalization of rugby union in 1995, and its concomitant financing and promotion by satellite television, has recently brought these two winter team sports into a more competitive situation with respect to fan recruitment and establishing a viable customer 
base. However, according to our fan survey data, compared to English soccer clubs Leicester Tigers typically recruits a rather older, more affluent fan cohort, one which is more usually drawn from the higher professional and non-manual social classes. Tigers' fans are drawn from the more desirable suburbs to the south of the city centre and from the cash-rich commuter urban villages in South Leicestershire. Around 28\% of Tigers season ticket fans are female, compared to around $24 \%$ of fans at soccer neighbours Leicester City (Williams, 2003; 2004).

Although rugby union in England has been growing in its wider economic and cultural importance in the 15 years since professionalization, it has also maintained the social cache of being the winter team sport which appeals mainly to the male white English middle and upper classes. Notwithstanding the recent relative 'feminization' of rugby crowds - at least in terms of numbers of female fans - rugby union also continues to prize its traditional role, as do tennis and golf clubs in England, as a hub for complex networks of middle class male sociability (Stacey, 1960). As Tony Collins (2006: 135) has pointed out, it is no accident that some English male rugby union fans still refer to their sport as 'a wonderful freemasonry'; a place where business might be conducted and men might gather to commune and network - ideally without the distractions of women. The Tigers club recruits few active ethnic minority fans - all our female interviews here are white - even though the city of Leicester is profoundly multi-cultural, including a large and well established South Asian community. Core, residual social class and ethnicity distinctions between and within professional male team sports clearly remain a strong feature of the sporting landscape in England, including in the city of Leicester. Let us now turn to our findings. 


\section{Findings}

The findings we present here focus on three key themes. Firstly, we examine women rugby union fans' early experiences of playing team sport and their interpolation with narratives about sports spectatorship; secondly, we consider the impact on sports attendance of changes in women's access to leisure time; and, finally, we address women's changing experiences of watching rugby union in the new so-called 'feminised' era. For reasons we have explored above, we are looking primarily here at older female Leicester Tigers fans (22 fans aged over 35 years) but very occasionally we do make reference to subjects in the larger host sample of Leicester soccer and rugby fans we examined $(\mathrm{N}=85)$. We refer to our interviewees by a simple letter and number code ( $\mathrm{F}=$ female soccer fans, $\mathrm{R}=$ female rugby union fans).

\section{i) Female rugby union fans' early experiences of sport}

Many boys are initially recruited as sports fans in England via the reflexive processes of fathering which ensure the normative early participation of (heterosexual) sons in contact team sport (see Kay, 2009). But for most female rugby union fans in England this avenue was - and is

- simply unavailable. For the 22 female rugby fans we consider here, none had opportunities to play school rugby or any similar contact male team sport. The only respondent in the wider project on female rugby and soccer fans in Leicester who had any experience of playing rugby union for a team was actually a younger soccer fan (F13), who had played briefly whilst at University. At school, our female respondents were typically channelled away from sport or into playing sports which, 'idealise popular images of femininity' rather than challenge or question 
them (Hargreaves 1988: 140). One older fan, who grew up in northern England near the working class rugby league stronghold of St Helens, discussed how educational and class identities often interpolated with, and occasionally overlaid, those of gender in this respect:

'The boys all played rugby union because that's what happened. We played rugby union in the grammar schools and rugby league was more working class, although we were all working class... So all my friends and my friends' brothers and cousins all played rugby union. So I used to go and watch school matches with them, but we all went to the [professional] rugby league matches.' (R31, Age 57, season ticket holder, geneticist)

An underlying theme running through the comments in our sample was that boys and girls did not typically 'mix' socially at school, let alone for PE lessons. In these accounts, even mixed school settings were essentially still divided along sex lines, both spatially and culturally. In short, established Victorian ideals and beliefs that women were antithetical to sport - inherently emotional, passive and gentle, unsuited for physical, competitive sport, the domain of men (see Hargreaves, 2002; McCrone, 1987; Vertinsky, 1990) - had clearly survived relatively unscathed well into the late $20^{\text {th }}$ century experience of English schooling. These women were typically resigned about even the possibility of girls playing contact sport at school: their typical socialisation, normative expectations and peer group assumptions automatically excluded them even from any distant consideration of team sport in this context:

'You didn't particularly think it was anything unusual because that's the way it was. It was only as you grow older and you suddenly realise, well, there's nothing stopping ladies playing football or rugby or, you know, men playing netball if they want. It was just one of those things. That's how it was; it was put into categories and it was just accepted.' (R16, age 53, season ticket holder, company secretary)

PE teachers in England interviewed in an early study by Sheila Scraton (1992: 50, 57) similarly dismissed 'masculine' sporting contact pursuits as naturally 'undesirable and unsuitable for 
girls', thus signalling a continuing, wider unwillingness among teachers in England to support girls in 'male' team sports (see Skelton, 2000; Swain, 2000; Welford and Kay, 2007). For our sample of older respondents educated in mixed-sex schools, compulsory sex segregation for PE meant that there was usually a female sports teacher for the girls and a male sports teacher for the boys, a fact which, crucially, also contributed to the normatively and stringently gendered consumption of sport as fans in both school and non-school settings:

'The boys would go to Twickenham [the RFU HQ] or [...] the football master would have taken the boys to Wembley to see perhaps schoolboy football. But $[\ldots]$ we would take the girls to Wembley to watch the women's hockey, as it was then. Cos that was a big thing then in the late 60s, early 70s, to go and watch England ladies play hockey.' (R17, age 55, season ticket holder, clerk)

A small number of active rugby union fans had explored the 'tomboy' identity option as youngsters, partly as a means of achieving better access to male play and team sport. For Paechter (2006) this acting as an 'honorary boy' means rejecting some of the disempowerment that comes with conventional femininity. Although these respondents typically remember being seen as 'strange' and 'odd' by 'more feminine' girls, the confidence and enjoyment gained from this tomboy persona was an empowering experience (see Cox \& Thompson, 2000; Paechter, 2006; Reay, 2001). For R22 (the only rugby interviewee who had actually played any junior rugby, albeit informally in family settings), assuming and performing a version of 'masculinity' in a largely male setting also helped shape her (often contradictory) gender identity later:

'I always think I'm a very unwomanly woman, cos - apart from the fact I have 50 pairs of high-heeled shoes (laughs) - I'm not into soap operas and I'm not into America's Next Top Model [reality TV show]... My idea of a perfect day is to take my dogs out for a run, have a quick shower and watch the rugby [...]. We watch sport [...] then films, I like things like Terminator and Star Wars; I'm not into chick flicks, they irritate me...I don't do things like that and I never have done. But I think it's probably my upbringing. It was 
a very male dominated household, my dad and my brothers, so that's how I was brought up.' (R22, age 48, season ticket holder, part-time teacher and designer)

There was widespread opposition in the sample to the idea that young females might routinely play rugby. Its aggressively invasive nature, combined with the very real risk of injury, often means that mothers oppose that their daughters - and indeed, in some cases, their sons - might be recruited to play competitive rugby. The recent women's rugby union World Cup finals, successfully held in England in 2010, might yet challenge dominant ideologies in this arena (see Gallagher, 2010). But this quite strong resistance among 'sporting' women to more female contact play is often rooted in highly essentialist assumptions. It views rugby as a deeply transgressive form of violent risk-taking; one which is simply just too challenging to sanction:

'It worries me that they [women] play. [...]. It worries me about the long-term effects of, if you're playing on a regular basis, and the contact. Because we're different from men, you know, from an anatomy point of view. We're very different [...]. If you're being knocked to the ground regularly I just wonder about our internal organs and the way we're made really.' (R19, age 54, season ticket holder, direct payments advisor)

\section{ii) Changes in women's access to leisure time}

By contrast to their own early experiences of sporting opportunity, our respondents used empowering terms such as: 'independent'; 'strong minded'; 'freer'; and 'more forceful' to describe the social condition of 'younger' women today. This new generation were seen, generally approvingly, as spirited and more reflexive agents, actors who will, 'Do what they wanna do. Sod it, if it's not stereotypical'. One of the possible outcomes here is women demanding - and acquiring - more latitude at spectator sports events. Seventeen out of the 22 older fans interviewed agreed that the proportion of female fans at Tigers matches had increased 
since professionalization in 1995. Notions of some kind of wider socio-structural 'gender convergence' in this context, which has allowed all women greater freedom and choice, remains a deeply contentious one of course (Wilkinson, 1994: 37). Such changes are at best uneven and they are highly refracted by the effects of interlocking inequalities along the fissures of cultural difference, age, race and class. For example, for R24 - and after a brief flirtation with soccer - it was not until all her children had grown up and left home that she felt she could pursue her own fan 'career' at the Tigers: 'Rugby came when it was my turn to do what I wanted to do'. As Green, Hebron and Woodward (1990: ix) point out, for most women leisure cannot be explored in isolation from other parts of their lives: a woman's 'right' to leisure is heavily 'circumscribed by her employment status and income level, her family situation and most important, her lack of status as a woman in a patriarchal society'. Similarly, Aitchison (2003: 42) claims that defining leisure as 'free time' raises issues for many women for whom freedom is dependent on the financial support of a male partner or their role as primary care providers for others. This is also one reason why some heterosexual men still feel they can control - or attempt to control - their female partners' leisure time.

The occupational background of our sample suggests they are likely to have more financial independence than many other women, but the link between more general changes in family life and the work sphere and the growing opportunities for women's leisure time was also crucial here, recalling especially Rosemary Deem's (1986: 40) early assertion that men feel they had a 'right to leisure' whereas many women do not. Our respondents broadly concurred that, with more women in waged work today - some as the main family breadwinner - women now feel as entitled to leisure time today as do men: 
'I don't know whether that's just the way of the world, if you like [...] The fact that you've got more women at work and possibly some households have perhaps got a little bit more disposable income because they've got two incomes, they can afford for them [male and female] both to go [to rugby] [...] Or whether because women have become more independent and perhaps more assertive, they make their own choices a little bit more. And I think you know, people get married later [...] and possibly having children later. So they're not at home tied up with the children [...]. I don't know whether those things connected.' (R20, Age 37, season ticket holder, financial director)

Attending sport with a husband or partner may once have seemed to reluctant women like a rather desperate way to stake a claim for more joint leisure time. But the perception today is that more women - especially, perhaps, those in more elevated class positions - are in a position to make their own choices, in terms of both their leisure and the time spent in the company of men. As R16 points out:

'I would think, going back quite a long way, football and rugby [were] predominantly male, because that was the men's time, that's what they did. So whether that's changed now because... we tend to mix more.... We don't have just female time and male time [...]. It's not ..."That's a man-only thing. We all meet up in the pub and then we go and watch. And women aren't included"'. (R16, Age 53, season ticket holder, company secretary)

This relative attrition of distinctions typically drawn between 'male time' and 'female time' in sport (and perhaps other) contexts is obviously a significant feature of recent developments in the lived experience of heterosexual couples. But how have women experienced these recent changes in the new so-called 'feminized' era of late-modern sport? We turn to this issue in the final section. 
iii) Women's changing experiences of watching sport

Amateur post-war English club rugby union offered basic facilities for spectators at best.

Accounts from older female fans of their early experiences of these male spaces are rare. As one of our more seasoned interviewees described it:

'I remember we used to stand behind the goal at the Welford Road end which was just a mud bank.... There used to be about ten of us altogether, and as I say I was eleven when I went down, but my dad didn't want to take me.... Well in those days, I mean, where the Crumbie Standing is, there just used to be a few people in the middle. That's all. Nothing like how it is today. (R25, age 70, season ticket holder, retired-worked as a machinist supervisor)

Following professionalism in 1995, rugby union attendances rose rapidly in England, provoking a period of stadium modernisation to match the aspirations and demands of the sport's new financers and customers. The Leicester Tigers for example, 'modernised' by building new stands and incorporating and extending bespoke executive facilities at Welford Road. Whilst these developments have been paraded locally as part of the club's more inclusive appeal to a new 'family' audience for rugby, they are also deeply rooted in plans to tap into regional corporate markets (Crowson, 2010). For our female respondents these reconstituted facilities, which also included a new club shop and more places to eat and drink at the ground, were part of a wider project to create a more seductive 'professional atmosphere' (R17) around English rugby. But not all respondents approved of the attempts to air-brush away the more visceral aspects of spectating in earlier periods. Recent attempts to get the club to share the nearby Walkers (soccer) Stadium, for example, were strongly opposed by both older and younger female Tigers fans. 
Instead, they expressed strong visceral attachments to the unique history and traditions of Welford Road:

'There's something about the Tigers ground. There's just something about the place. When they were going to move us to the Walkers [Stadium], you know, I really didn't want to move. It's just something I want to.... I took the grandchildren, but it's something I want my grandchildren's children to go to. You know, it becomes part of you, I think.' (R33, age 57, season ticket holder, computer supervisor)

'One of my favourite places in the world is Welford Road; it just is magic when you get in [...]. I love it. I love...just the smell. Where we stand, we're near the [players'] tunnel, cos that's where the players sit. I can be anywhere and get a whiff of Deep Heat. I'm on the terrace in the rain smelling Deep Heat on a Friday night or a Saturday afternoon. ...I've not been to another stadium that has made me feel like Welford Road feels; there is a buzz about the place.' (R1, Age 25, season ticket holder, principal office clerk)

McDowell (1999: 11) points out that there are deep-seated and highly gendered assumptions about the 'natural' and built environments; about who should occupy space and who should be excluded. It often requires energy and organisation to gain even the most basic acknowledgement of women's presence in buildings (Darke, 1996). Thus, there is a continued requirement to highlight the apparent 'naturalness' of gender and spatial divisions within the architecture of the 'man's world' of everyday sporting life. This means that despite the professionalism and the 'improved' facilities at Welford Road in the supposed new feminized era of the sport, impacted patriarchal design raised familiar and bitter complaints from women and predictable calls for what many regarded as necessary change. As one of our respondents put it:

'The gripe, gripe, gripe that I have is ladies toilets. Lack of them: and lack of... just general understanding of what a lady might want in a toilet! [....] And I've complained about it before but it falls on deaf ears [...]. My view is it is a man's club; it is a man's world and until women start to get on the board or whatever [...] But I don't think that's 
going to happen for a few years yet.' (R14, age 45, season ticket holder, learning mentor)

Collins (2009) has suggested that the arrival of professionalism has made rugby union much more 'fashionable' than hitherto and for our respondents part of this trajectory has involved the ways in which, with full-time salaries and vigorous training regimes, senior players had worked and toned their bodies and become 'leaner and fitter today' (R25) and thus more obviously attractive to heterosexual female fans (R13, R17, R19, R20, R23, R24, R26, R29, R30, R34). Connected to this point, our respondents routinely aligned their sport to a morally superior masculinity code compared to that at soccer - to a benign and honourable version of Connell's (1995) dominant 'hegemonic masculinity.' For example, they typically ridiculed soccer fans for following and playing a sport allegedly characterised by 'subordinate' forms of masculinity in a way that drew on class-inflected forms of difference and obviously homophobic connotations:

\begin{abstract}
'A City supporter would say that soccer is a really skilful game, but a rugby player, a rugby supporter would probably.... make some derogatory comment about how weak they are, or namby-pambys, you know. They'd be a bit more homophobic than that, if you get what I'm saying (laughs). They'd basically say you're a woman or you're a poofter, you know, that sort of comment. It doesn't take much to play soccer, but to play rugby you've got to be a real man (laughs).' (R19, Age 54, season ticket holder, direct payments advisor)
\end{abstract}

This recent development of player body capital and the promotion of 'real men' in rugby union was coupled for our respondents with the way that saturation television coverage had 'opened up' sport for women in recent years - thus making rugby union more accessible and more intelligible to new spectators via the media's glitzy presentational styles and its increasing focus on 'personalities' (R14, R17, R19, R32). These new corporeal attractions, enhanced by an extended media coverage and innovative marketing techniques in the age of celebrity, are argued 
to have brought new women followers into the sport - who may then go on to become more knowledgeable about its core features:

'There's a huge amount of television coverage now then there ever was. You know, you would get one game a year, the John Player Cup, and you would get the internationals on the TV, and that would be it... Now... obviously with Sky you know, you've got this weekend full, Friday night to Sunday night solid...It was the popularity of the game and the awareness raising of the game that obviously has brought them [new women] into it.' (R14, Age 45, season ticket holder, learning mentor)

'The pin ups, the Johnny Wilkinsons and that sort of thing. It might get women interested to start with. And, hopefully they get interested in the game then and not just... (laughs).' (R13, Age 42, season ticket holder, housewife)

But perhaps partly because of the impact of some of these recent changes, our interviewees also knew full well that they were still expected routinely to demonstrate publicly to men their knowledge and commitment as sports fans. For example, R29 described how men often 'test' women's knowledge so: 'You've got to prove you know what you're talking about, whereas women just assume that other men know what they're talking about'. This questioning of sporting authenticity and loyalty among female fans could perhaps best be seen: 'as an expression of men's fears over women invading their traditionally masculine space' (Gosling, 2007: 260). It also presents women fans with the complex challenges of routinely negotiating in their sports practices the gender paradox - the demonstration of competency and knowledge by (lower status) females in roles traditionally claimed by (higher status) men in the context of hegemonic masculinity (Martin, Schouten and McAlexander, 2006: 183). In this sense - and despite the prevailing rhetorics about feminising sporting cultures - women sports fans still regularly contest male condescension in sporting landscapes and also face the fact that they are mainly tolerated in sports crowds as, at best, 'honorary' males (Ben-Porat, 2009: 888). 


\section{Conclusion}

Our main aim in this paper has been to begin to explore the experiences of a sample of usually invisible, 'ordinary' female sports fans in England as a means of countering the dominant qualitative research focus in sport on more 'spectacular' male fans. We have also aimed to begin to unpack and challenge some of the common assumptions about the extent to which - and in what ways - late-modern sports crowds and sports spaces have become 'feminized.' In this context we have effectively been exploring multiple feminisms: ways in which some women see sports spectatorship as part of an identity project in which they expand, complicate and empower their own femininities (Martin et al, 2006: 190), while for others it offers something closer to a contingent form of gender tourism (Moore, 1988.) We have concentrated mainly here on examining the views and experiences of a small sample of older female rugby union fans of the Leicester Tigers club in the East Midlands of England. This is as a counter to the tendency - in Europe at least - to assume that fan experiences from soccer can easily be generalised to all sports.

We have been restricted by space to examining empirically, very briefly, three core themes which have come out of a wider research project on female sports spectators in Leicester: the early sporting experience of female rugby fans and its possible relation to the production later of female sports spectator 'careers'; the extent to which wider social and cultural changes in gender relations have helped shape and inform recent female sports fan experiences in England; and, finally, the changing experience of women rugby union fans of sporting cultures, stadium spaces 
and sporting places against the backcloth of a new media agenda for sport and a generally 'masculinised' discourse about English sporting traditions and heritage. Taken together, these three strands begin to map elaborate patterns of continuities and change in women's often hidden experiences as sports fans and start to sketch out their impact on English sporting landscapes and cultures. This is even though English rugby union has only really begun to see itself as a serious competitor in the marketplace for sports customers - and for female fans - in the last two decades.

Some of the common tropes of the supposed recent 'feminization' of the English sports crowd spectator gentrification; the promotion of heterosexual player glamour and celebrity; the attractions of modern, rationalised stadia to the 'family' audience for sport; the relative wider empowerment of women and their increasing opportunities to play contact team sport; and the greater relative acceptance of women by men as 'authentic' sports spectators - all play out in some respect here. But they also do so only in complex, contradictory and often contested ways. The issue of female 'entitlement' to their own personal histories as fans, the changing nature of the meaning of spectator sport for younger female sports fans raised in a period suffused with the vortex of celebrity (Whannel, 2002), and the intimate and visceral seductions of traditional sports spaces and sports heritage for some female spectators, offer themselves as potential channels for future research and we are beginning to address some of these issues ourselves. It will be important to examine questions of empowerment and resistance around the existence and performance of women spectators in different sports to soccer and the one we have briefly considered here, rugby union. 
Finally, the extent to which the greater presence of women in sports crowds today, in and of itself, constitutes a process of 'feminization' in sporting cultures remains a deeply contentious issue, as we have tried to illustrate here. Indeed, some of the ways in which our own respondents conceptualise gender difference in sporting contexts and the manner in which, for example, TV coverage of sport - including rugby union - 'naturally' pans to conventionally attractive young female faces in sports crowds during gaps in play, demonstrates both the increasingly central role younger women play in the marketing of spectator sport today, but also that many of the established conventions around the gender/sport axis remain relatively undisturbed by recent changes. To what extent women as active fans bring quite different behaviour patterns, sensibilities and values to late-modern sports stadia is a question we have at least begun to embark upon. It is one which clearly needs to continue to be addressed both theoretically and empirically. In short, we need much more research on these previously 'invisible' and largely unconsidered fans of professional spectator sport in order to illuminate marginalised voices without the limitations of a single critical perspective (Martin et al, 2006: 191). This is not least because the growing number of active female sports fans and their increasing visibility at sports stadia is routinely advertised today by those who govern global sport as a signal of spectator sport's transformative, progressive potential. 


\section{References}

Aitchison, C. (2003) Gender and Leisure: Social and Cultural Perspectives. London: Routledge.

Andrews, D. and Ritzer, G. (2007) 'The grobal in the sporting glocal' Global Networks 7 (2) pp. 113-153.

Ang, I. (1991) Watching Dallas: Soap Opera and the Melodramatic Imagination. London: Routledge.

Barbas, S. (2001) Movie Crazy: Fans, Stars and the Cult of Celebrity. Hampshire: Palgrave Macmillan.

Ben-Porat, A. (2009) 'Not just for men: Israeli women who fancy football' Soccer and Society 10 (6) pp. 883-896.

Cere, R. (2003) 'Witches of our age: women ultras, Italian football and the media' in A. Bernstein and N. Blain (eds.) Sport, Media, Culture: Global and Local Dimensions pp. 166-188. London: Frank Cass.

Chen, P, J. (2010) 'Differences between male and female sport event tourists: a qualitative study' International Journal of Hospitality Management 29, pp. 277-290.

Clark, J. Apostolopoulou, A. and Gladden, J. (2009) 'Real women watch football: gender differences in the consumption of the NFL Super Bowl broadcast' Journal of Promotion Management, 15, pp. 165-83.

Cline, C. (1992) 'Essays from Bitch: the woman's rock newsletter with bite' in L. Lewis (ed.) The Adoring Audience: Fan Culture and Popular Media 69-83. London: Routledge.

Collins, T. (2006) Rugby League in Twentieth Century Britain: A Social and Cultural History. London: Routledge.

Collins, T. (2009) A Social History of English Rugby Union. London: Routledge.

Conn, D. (1997) The Football Business: Fair Game in the 1990s?. Edinburgh: Mainstream Press.

Connell, R. (1995) Masculinities. Cambridge: Polity Press.

Cox, B. and Thompson, S. (2000) 'Multiple bodies: sportswomen, soccer and sexuality' International Review for the Sociology of Sport 35 (1) pp. 5-20. 
Crawford, G. and Gosling, K. (2004) 'The myth of the "Puck Bunny": female fans and men's ice hockey’ Sociology 38 (3) pp. 477-93.

Crolley, L. and Long, C. (2001) 'Sitting pretty? Women and football in Liverpool' in J. Williams, S. Hopkins and C. Long (eds.) Passing Rhythms: Liverpool FC and the Transformation of Football pp. 195-214. Oxford: Berg.

Crowson, M. (2010) 'Tigers' plans are on track' Leicester Mercury 8 September.

Darke, J. (1996) 'The man-shaped city' in C. Booth, J. Darke, and S. Yeandle (eds.) Changing Places: Women's Lives in the City pp. 88-99. London: Paul Chapman.

Deem, R. (1986) All Work and No play? The Sociology of Women's Leisure. Milton Keynes: Open University.

Dietz-Uhler, B., Harrick, E., and End, C. (2000) 'Sex differences in sport fan behavior and reasons for being a sport fan’ Journal of Sport Behavior 23 (3) pp. 219-231.

Ehrenreich, B., Hess, E., and Jacobs, G. (1992) 'Beatlemania: girls just wanna have fun' in L. Lewis (ed.) The Adoring Audience: Fan Culture and Popular Media, pp. 84-106. London: Routledge.

Free, M. and Hughson, J. (2003) 'Settling accounts with hooligans: gender blindness in football supporters' subculture research' Men and Masculinities 6 (2) pp. 136-55.

Funk, D, Ridinger, L. and Moorman, A. (2004) 'Exploring origins of involvement: understanding the relationship between consumer motives and involvement with professional sport teams' Leisure Sciences 26 (1) pp. 25-61.

Gallagher, B. 'No novelty here, just good rugby' The Sunday Telegraph 5 September 2010.

Giulianotti, R. (1999) Football: a Sociology of the Global Game. Cambridge: Polity.

Giulianotti, R. and Robertson, R. (2004) 'The globalization of football: a study in the glocalization of the "serious life" British Journal of Sociology 55 (4) pp. 545-563.

Gosling, V. (2007) 'Girls allowed? The marginalisation of female sports fans' in J. Gray, C. Sandvoss and C Lee Harrington (eds.) Fandom: Identities and Communities in a Mediated World, pp. 250-260. New York: University Press.

Green, E. Hebron, S. and Woodward, D. (1990) Women's Leisure, What Leisure?. London: Macmillan Education.

Hargreaves, J. (1988) 'The promise and problems of women's leisure in sport' in C. Rojek (ed.) Leisure For Leisure pp. 130-149. Hampshire: Macmillan. 
Hargreaves, J. (2002) 'The Victorian cult of the family and the early years of female sport' in S. Scraton and A. Flintoff (eds) Gender and Sport: A Reader. London: Routledge.

Harrington, C. and Bielby, D (1995) Soap Fans: Pursuing Pleasure and Making Meaning in Everyday Life. Philadelphia: Temple University Press.

Harris, C. (1998) 'Introduction' in C. Harris and A. Alexander (eds.) Theorizing Fandom: Fans, Subculture and Identity pp. 3-8. New Jersey: Hampton Press.

Harvey, D. (2005) Football, the First Hundred Years: The Untold Story. London: Routlege.

Hinerman, S. (1992) '"I'll be here with you." Fans, fantasy and the figure of Elvis', in L. Lewis (ed.) The Adoring Audience: Fan Culture and Popular Media pp. 107-134. London: Routledge.

Jenkins, H. (1992) Textual Poachers: Television Fans of Participatory Culture. London:

Routledge.

Jenson, J. (1992) 'Fandom as pathology: the consequences of characterization' in L. Lewis (ed.) The Adoring Audience: Fan Culture and Popular Media pp. 9-29. London: Routledge.

Jones, K. (2008) 'Female fandom: identity, sexism and men's professional football in England' Sociology of Sport Journal 25: pp. 516-37.

Kay, T. (2009) 'Fathers and sons: being "Father Angel"' in T. Kay (ed.) Fatherhood Through Sport and Leisure. London: Routledge.

Kilborn, R. (2003) Staging the Real: Factual TV Programming in the Age of Big Brother. Manchester: Manchester University Press.

Kim, H. M. (2004) 'Feminization of the 2002 World Cup and women's fandom' Inter-Asia Cultural Studies 5 (1) pp. 42-51.

King, A. (2002) The End of the Terraces. London: Leicester University Press.

Lewis, R. (2009) “'Our lady specialists at Pikes Lane': Female spectators in early English professional football, 1880-1914' The International Journal of the History of Sport 26 (15) pp. 2161-2181.

Lopez, S. (1997) Women on the Ball (London: Scarlet Press)

Martin, D., Schouten, J, \& McAlexander, J (2006) 'Claiming the throttle: multiple femininities ina hyper-masculine subculture’ Consumption, Markets and Culture 9 (3): 171-205.

McCrone, K. (1987) 'Play up! Play up! Play up and play the game! Sport in the late-Victorian girls' public schools' in J. Mangan \& R. Park (eds.) From Fair Sex to Feminism pp. 97-129. London: Frank Cass. 
McDowell, L. (1999) Gender, Identity and Place. Cambridge: Polity Press.

Mewett, P. and Toffoletti, K. (2008a) 'Rogue men and predatory women: female fans' perceptions of Australian footballers' sexual conduct' International Review for the Sociology of Sport 43 (2) pp. 165-80.

Mewett, P. and Toffoletti, K. (2008b) 'The strength of strong ties: how women become supporters of Australian Rules Football', TASA 2008, Re-imagining Sociology: The Annual Conference of the Australian Sociological Association, University of Melbourne: Melbourne.

Moore, S. (1988) Getting a bit of the other: the pimps of post-modernism' in R. Chapman and J. Sutherland (eds.) Male Order: Unwrapping Masculinity pp. 165-92. London: Lawrence and Wishart.

Nash, R. (2000) 'Contestation in modern football' International Review for the Sociology of Sport 35 (4) pp. 465-486.

Nash, R. (2001) 'English football fan groups in the 1990s: Class, representation and fan power Soccer and Society 2 (1) pp. 39-58.

Paechter, C. (2006) 'Masculine femininities/feminine masculinities: power, identities and gender' Gender and Education, 18 (3) pp. 253-63.

Pope. S. (2008) 'Out in the field' Sociology Review 17 (4) pp. 14-16.

Pope, S. (2010) 'Female fandom in an English "Sports City": a sociological study of female spectating and consumption around sport' unpublished $\mathrm{PhD}$, University of Leicester.

Reay, D. (2001) '"Spice girls, "nice girls" "girlies" and "tomboys": gender discourses, girls' cultures and femininities in the primary classroom' Gender and Education13 (2) pp. 153-66.

Robinson, M. and Trail, G (2005) 'Relationships among spectator gender, motives, points of attachment and sport preference' Journal of Sport Management, 19 pp. 58-80.

Rodríguez, M. (2005) 'The place of women in Argentinian football' The International Journal of the History of Sport 22 (2) pp. 231-45.

Sandvoss C. (2003) A Game of Two Halves: Football, Television and Globalization. Cambridge: Polity Press.

Scraton, S. (1992) Shaping Up Womenhood: Gender and Girls' Physical Education. Buckingham: Open University.

Shildrick, T. and MacDonald, R. (2006) 'In defence of subculture', Journal of Youth Studies, 9 (2) pp. 125-40. 
Skelton, C. (2000) “A passion for football': Dominant masculinities and primary schooling' Sport, Education and Society 5 (1) pp. 5-18.

Smith, A. and Stewart, B. (2007) 'The travelling fan: understanding the mechanisms of sport fan consumption in a sports tourism setting' Journal of Sport and Tourism, 12 (3-4) pp. 155-81.

Spence, L. (2005) Watching Daytime Soap Operas: The Power of Pleasure. Middletown: Wesleyan University Press.

Stacey, M. (1960) Tradition and Change: A Study of Banbury. London: Oxford University Press.

Swain, J. (2000) “'The money's good, the fame's good, the girls are good': The role of playground football in the construction of young boys masculinity in a junior school' British Journal of Sociology of Education 21 (1) pp. 95-109.

Taylor, H. (1989) Scarlett's Women: Gone With the Wind and its Female Fans. London: Virago Press.

Vertinsky, P. (1990) The Eternally Wounded Woman: Exercise and Doctors in the Late Nineteenth Century. Manchester: Manchester University Press.

Wann, D. Melnick, M. Russell, G. and Pease, D. (2001) Sport Fans: the Psychology and Social Impact of Spectators. London: Routledge.

Welford, J. and Kay, T. (2007) 'Negotiating barriers to entering and participating in football: Strategies employed by female footballers in the United Kingdom' in J. Magee, J. Caudwell, K. Liston \& S. Scraton (eds.) Women, Football and Europe pp. 151-171. Oxford: Meyer \& Meyer Sport.

Whannel, G. (2002) Media Sports Stars. London: Routledge.

Wilkinson, H. (1994) No Turning Back: Generations and the Gender Quake. London: Demos.

Williams, J. (2000) 'The changing face of football: a case for national regulation?' in S. Hamil, J. Mitchie, C. Oughton and S. Warby (eds.) Football in the Digital Age: Whose Game is it Anyway? pp. 94-106. Edinburgh: Mainstream Press.

Williams, J. (2003) A National Survey of Premiership Rugby Fans. Leicester: Leicester University.

Williams, J. (2004) A Survey of Leicester City Football Fans. Leicester: University of Leicester.

Williams, J (2006) "'Protect me from what I want": football fandom, celebrity cultures and "new" football in England, Soccer in Society 7 (1): 96-114. 
Williams, J. and Perkins, S. (1998) Ticket Prices, Football Business and Excluded Fans: a Report to the Football Task Force. Leicester: University of Leicester. 